\title{
Consumir e ser consumido: uma análise discursiva das novas exigências da vida online
}

\section{Danielle Cândido}

Doutoranda em Linguística pela Universidade Federal de Alagoas (UFAL), Brasil

orcid.org/0000-0002-8954-6688

\author{
Maria Virgínia Borges Amaral \\ Professora Titular da Universidade Federal de Alagoas \\ (UFAL), Brasil \\ orcid.org/0000-0002-6112-984X
}

Este artigo põe em questão a condição de sofrimento do sujeito que consome e é consumido pelas novas exigências da vida online. Para tal reflexão, o estudo tem o objetivo de analisar as estratégias argumentativas do discurso do mercado que enaltecem a competitividade como valor a ser perseguido e apelam ao medo/ansiedade para incitar o temor a fim de conseguir submissão e aquiescência. Tendo em conta as contribuições da Análise do Discurso de Michel Pêcheux e da Teoria da Argumentação, procura-se demonstrar que o neoliberalismo gesta, administra e conduz o sofrimento humano, que é um sintoma da sociedade de consumo.

Palavras-chave: Discurso. Argumentação. Consumo. FoMO.

\section{Consumir y ser consumido: un análisis discursivo de las nuevas demandas de la vida online}

Este artículo cuestiona la condición de sufrimiento del sujeto que consume y es consumido por las nuevas exigencias de la vida online. Para tal reflexión, el estudio tiene como objetivo analizar las estrategias argumentativas del discurso de mercado que ensalzan la competitividad como un valor a perseguir y apelan al miedo/ansiedad para incitar el temor con el fin de lograr la sumisión y la conformidad. Teniendo en cuenta las contribuciones del Análisis del Discurso de Michel Pêcheux y la Teoría de la Argumentación, buscamos demostrar que el neoliberalismo genera, gestiona y conduce el sufrimiento humano, síntoma de la sociedad de consumo.

Palabras clave: Discurso. Argumentación. Consumo. FoMO.

\section{To consume and to be consumed: A discursive analysis of the new demands of online life}

This article questions the suffering condition of the subject who consumes and is consumed by the new demands of online life. To reflect upon the topic presented herein, the study aims to analyze market discourse strategies that enhance the relationship as a value to be pursued and that appeal to fear/anxiety to incite unease in order to achieve submission and acquiescence. Considering the contributions from both Michel Pêcheux's Discourse Analysis and Argumentation Theory, we seek to demonstrate that neoliberalism generates, manages and conducts human suffering, which is a symptom of the consumer society.

Keywords: Discourse. Argumentation. Consumption. FoMO. 


\section{Introdução}

O objeto de estudo deste artigo são os discursos que circulam na sociedade contemporânea "conectada"1 ao consumo, os quais acendem uma discussão sobre as regras ditadas pelo mercado como estratégias discursivas que conduzem o sujeito para o sofrimento de consumir e ser consumido pelas novas exigências da vida online. A contextualização do objeto se centra no fato de que essa discussão acontece no momento que o crescimento do ambiente virtual apresenta novas realidades que modificaram as práticas de vida, agora voltadas para o consumo. Isto é, uma vida pensada para ser exibida a fim de provar o próprio reconhecimento e, consequentemente, causar inveja no outro que, ao buscar por informação, será também conduzido pelo desejo de comprar/vender e o de possuir e ser (SOLOMON, 2016).

É nesse contexto que os sujeitos consumidores são contaminados pelo temor de perder algo, como o "medo de ficar de fora" (do inglês, Fear of Missing Out - FoMO) do boom de informações que os internautas compartilham nas plataformas digitais. De acordo com artigo de O Estado de S. Paulo (2011), o termo FoMO foi utilizado pela primeira vez no jornal The New York Times, em 2011, e alertou o público sobre o que poderia ser um sintoma do uso exacerbado da tecnologia digital, que ocorre quando uma pessoa se sente excluída ao notar, por meio das redes sociais digitais, que os outros estão fazendo algo que ela não está. Esse medo de perder - ou a perda propriamente dita - sempre existiu (O ESTADO DE S. PAULO, 2011). Porém, numa contemporaneidade tão afetada pelas tecnologias digitais, a situação se agrava: 0 internauta não pode, não consegue e não quer desconectar.

Na direção de uma "vida para o consumo" (BAUMAN, 2008), o sujeito está sempre online, numa prontidão emblemática, e, assim, sente-se ilusoriamente mais seguro por saber que pode se comunicar e se manter informado o tempo todo. O comportamento FoMO é, de acordo com o estudo que desenvolvemos neste artigo, um dos exemplos mais relevantes do uso contemporâneo da internet: a autopropaganda. Quanto mais determinado o usuário estiver de provar o seu reconhecimento, ou seja, de que está "vivendo a vida", mais medo/ansiedade isso causa em seus seguidores, os quais, então, sentir-se-ão impelidos a fazer o mesmo. Esse é um processo que se retroalimenta.

Nessa linha, o objetivo deste artigo é entender, a partir da Teoria da Argumentação, como os meios discursivos (logos, ethos, pathos) e os afetos são mobilizados para o funcionamento do discurso do mercado ${ }^{2}$. Para esse intento, o estudo

\footnotetext{
${ }^{1}$ A expressão "conectada" denota dois sentidos interdependentes: primeiro, o de conexão com a internet; segundo, 0 de conexão entre pessoas para efetuarem compras e vendas, firmarem identidade de sujeitos, que o são ao possuir. 2 Em "Discurso e relações de trabalho", Amaral (2016) explica que os elementos de saber da Formação Discursiva do Mercado estão ancorados em fundamentos da Formação Ideológica do Capital, a qual considera as determinações
} 
busca analisar as estratégias argumentativas do discurso do mercado que enaltecem a competitividade e que apelam ao medo/ansiedade como forma de persuasão.

Nesse cenário, é possível mobilizar gestos de descrição e interpretação do discurso do mercado, materializado nas palavras que circulam nas redes sociais digitais. De acordo com Courtine (2016a), tais palavras podem ser a existência material essencial do sofrimento: a ansiedade pode ser a situação de sofrimento que o sujeito teme experimentar. A materialidade linguístico-discursiva " $E$ fora do story, você tá bem?"3 (que circulou no meio digital em agosto de 2021) põe em questão a condição do sujeito fora do cenário discursivo digital. O discurso do mercado se apropria dessa instabilidade para aprisionar o sujeito ao universo digital, do qual se serve para responder aos propósitos da sociedade capitalista.

O meme "E fora do story, você tá bem?" é uma referência à vida "perfeita" mostrada na internet. Demonstra, ainda, o quanto as pessoas sofrem com as comparações com o outro - um objeto de desejo insaciável. A materialidade linguísticodiscursiva também representa uma resposta aos princípios propagados pela lógica neoliberal, os quais apresentam efeitos de positividade sobre a busca de liberdade, autonomia e reconhecimento, mas que silenciam sobre o caráter negativo da competitividade (DARDOT; LAVAL, 2016). Do material da língua (o meme), chega-se ao discurso do mercado (o processo de sustentação da ordem vigente que enaltece a competitividade como valor a ser perseguido).

Para tal análise, a fundamentação teórico-metodológica desta pesquisa está ancorada na Análise do Discurso (AD) pêcheutiana, sustentada no materialismo histórico, com uma reflexão sobre o lugar da argumentação no discurso, a partir da leitura de Amossy $(2011,2018)$. A presente proposta de diálogo teórico entre a Análise do Discurso pêcheutiana e a Teoria da Argumentação visa a contribuir com a análise, por meio do processo de identificação dos elementos de saber que fazem funcionar as estratégias de argumentação no discurso do mercado, a exemplo dos meios discursivos que o processo de persuasão mobiliza - o logos, o ethos e o pathos. O grande marco de Aristóteles, em Retórica, foi a união desses três elementos que estiveram presentes nos discursos, além de atribuir à retórica o objetivo de conhecer os meios de persuasão, e não o de persuadir.

do mercado como o único caminho para a felicidade e a liberdade do homem. No entanto, tal formação ideológica assim o faz negando e ocultando o conflito de classes, simulando evidências de homogeneidade na sociedade.

3 A matéria do portal Terra "\#foradostory, você tá bem?", de Julia Natulini (2021), permite ao leitor se inteirar do assunto.

4 De acordo com Mari Jr. e Michelan (2019), o meme é um formato de comunicação comum na internet, que combina texto e imagem em mensagens curtas e quase sempre em tom de humor, mas que podem conter importantes significados e serem bastante úteis para os membros de uma comunidade online. 
Entende-se que os discursos que circulam com base no apelo ao medo/ansiedade incitam o temor para conseguir submissão e aquiescência dos sujeitos. Isso acontece porque o neoliberalismo instrumentalizou o sofrimento para ganhos de produtividade dos trabalhadores e atenuação de possíveis revoltas políticas. O adoecimento que hoje acomete o sujeito é um sintoma da sociedade de consumo, que, por um lado, apresenta a competição de todos contra todos como um caráter positivo para a concorrência; por outro lado, pune com a exclusão social e a falta de direito à solidariedade ou qualquer espaço de comunhão aqueles que não se adéquam ou se inserem nesta sociedade. Conforme descreve Han (2015), autor de "Sociedade do cansaço", o neoliberalismo gesta, administra e conduz o sofrimento humano.

\section{Meios discursivos, capitalismo e sofrimento}

Por meio do estudo e do embate de ideias, Aristóteles compôs uma de suas grandes obras, a Retórica, na qual o filósofo divide este saber em três pilares: logos, ethos e pathos. A retórica poderia ser definida como a arte de escolher o melhor argumento a cada caso com fins de persuasão. Nesse sentido, é preciso sublinhar que "o logos, entendido como discurso e razão, é, para Aristóteles, simplesmente um dos polos do empreendimento de persuasão retórica" (AMOSSY, 2018, p. 18). Ou seja, o logos é a argumentação racional que pretende persuadir pelas vias do argumento e da prova. No entanto, as provas inerentes ao discurso são de três espécies. Enquanto no logos as provas residem no próprio discurso; no ethos, as provas estão no caráter moral do orador; e no pathos, na disposição do auditório. Esses meios discursivos conferem ao texto (materialidade linguístico-discursiva) sua força de persuasão.

A importância do ethos está na imagem que o orador projeta de si mesmo em seu discurso, o que contribuiu para assegurar sua credibilidade e autoridade: "As pessoas se deixam mais facilmente persuadir por um homem cuja probidade é conhecida do que por uma pessoa de honestidade duvidosa" (AMOSSY, 2018, p. 18). Já o espaço do pathos é atribuído à emoção que o orador busca suscitar em seu auditório, "pois é importante tanto comover quanto convencer, caso se queira conseguir a adesão e modelar comportamentos" (AMOSSY, 2018, p. 18).

É relevante destacar, ainda, que a retórica aristotélica considera, segundo Amossy (2018, p. 18), "a força da palavra um motor da ação social no seio de uma visão em que (1) a figura do locutor tem um papel determinante e (2) razão e paixão estão interligadas", conforme é possível observar na figura a seguir, que representa os meios discursivos funcionando na estratégia argumentativa do discurso do mercado. 
Figura 1 - Meios discursivos

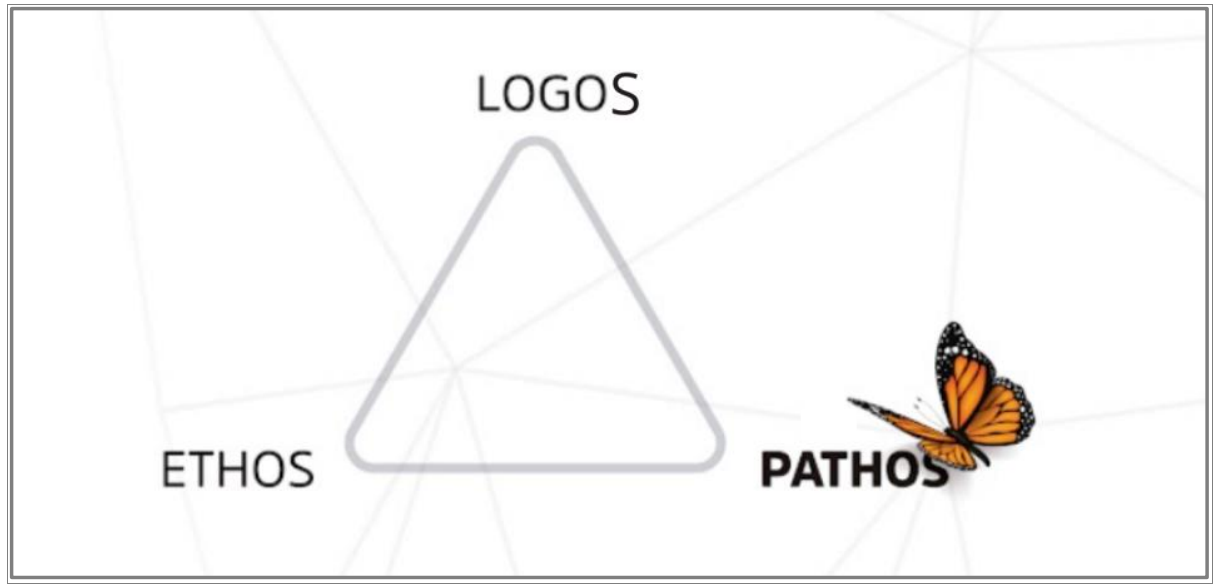

Fonte: Elaboração própria

Na Figura 1, a imagem da borboleta no processo discursivo representa o efeito da emoção no discurso do locutor, que argumenta com o intuito de provocar seu auditório, visto que, na argumentação que se baseia na emoção, está presente a "exploração fremente dos sentidos, do entusiasmo, de uma condição de existência dramática ou jubilosa" (CARRASCOZA, 2004, p. 32). O foco no efeito de emoção no argumento para fins de convencimento, isto é, da metamorfose lagarta-borboleta, leva ainda a pensar sobre a seguinte questão: de que forma os meios discursivos, em especial o pathos, fazem-se presentes no discurso do mercado dirigido a um sujeito, cujo comportamento é descrito como FoMO, que significa, em português, o "medo de ficar de fora"?

Essa pergunta é importante para entender a materialidade discursiva em análise, o post em rede social digital "Leia esse texto: o que as pessoas compram, na verdade?", extraído do perfil do Instagram @keylagabrielleoficial (GABRIELLE, 2021), mentora de marketing digital que acumula pouco mais de 58 mil seguidores. O critério de escolha dessa rede social digital se deve ao fato de o Brasil ser o terceiro no ranking de maior número de usuários do Instagram, sendo esta a quarta mídia social mais usada pelos brasileiros em 2021. O perfil da mentora Keyla Gabrielle foi escolhido porque ela é referência, em Alagoas, na formação de empreendedores para a utilização desta rede social como ferramenta de venda, tendo capacitado mais de 5 mil alunos desde 2017.

Essa postagem foi selecionada para análise porque o discurso da mentora digital demonstra como as estratégias argumentativas do discurso do mercado enaltecem a competitividade como valor a ser perseguido e apelam ao medo/ansiedade como forma de persuasão. Na própria biografia do Instagram, a intenção argumentativa está posta na descrição: "Mentora de mulheres que desejam posicionar sua marca pessoal e escalar seu ticket através do digital". Para a análise, reproduzimos a sequência discursiva (SD), cujo conceito, dado por Courtine (2016b, p. 25), é o de uma 
"manifestação da realização de um intradiscurso", isto é, do dizer atual. A partir desta definição, consideramos a SD01:

SD01 - Para de vender os benefícios dos seus produtos/serviços e se concentre na intangibilidade que eles proporcionam. Qual a EMOÇÃO que seu cliente compra ao adquirir o seu produto? [...]. Você está falando sobre esses SENTIMENTOS nos seus conteúdos? Ou está tentando vender o frasco do perfume?

O post mescla o discurso pedagógico (a mentora ensina a vender produto/serviço na mídia digital) e o discurso do mercado (a mentora vende o produto anunciado: a mentoria de posicionamento digital). É possível ver essa estratégia de dimensão argumentativa (quando a persuasão ocorre de forma indireta) também em anúncios como "É menos sobre você e mais sobre quem você pode ajudar" (DANTAS, 2021), que reforça a tese máxima do discurso publicitário, "o secundário é o principal" (CARRASCOZA, 2014, p. 24), anunciada por Fernando Pessoa (apud FERREIRA, 1986) como uma das teses máximas da Publicidade e Propaganda.

Ainda com a SD01, pode-se identificar que o discurso argumentativo coloca o consumidor no centro da linha de força para a persuasão. Isso significa que o meio discursivo pathos é utilizado para dar evidência à audiência, que é instruída/moldada a comunicar sobre o produto/serviço, de modo a destacar de que modo esse produto/serviço pode transformar a vida das pessoas, mas faz isso focando nelas mesmas. É nesse sentido que se explica a tese máxima da publicidade: a de que o secundário (ajudar) é o principal (venda do produto/serviço), em se tratando de estratégias discursivas para fins de convencimento pela via da emoção. Em outros termos, em vez de falar sobre o produto/serviço, deve-se falar sobre como esse produto/serviço ajuda o outro, dando, assim, ênfase à audiência.

Para isso, o discurso da publicidade [...] configurou [...] um caleidoscópio retórico cujo eixo - fiel à sua finalidade persuasiva de conquistar a adesão de outrem empregando a suavidade ou o choque - está em ocultar, ao menos inicialmente, seu real intuito. [...] a estrutura de um anúncio parte de uma informação secundária (um ponto de vista ou uma comparação, por exemplo) para, em seguida, no desdobramento do seu circuito discursivo, apresentar o principal (o produto ou 0 serviço) (CARRASCOZA, 2014, p. 25-26).

Em meio ao conhecimento compartilhado e à necessidade de ação, os usuários da internet têm utilizado as redes sociais digitais de forma intensa e grave, o que é reforçado pelas mensagens com caráter de intenção argumentativa presentes em anúncios que circulam na internet. "Aprenda a ganhar dinheiro no Instagram com o engajamento dos seus seguidores", anúncio da empresa Shopify (que desenvolve softwares de computadores para lojas online e sistemas de varejo de ponto de venda), é um exemplo do discurso do mercado que leva o sujeito ao uso exacerbado das redes sociais digitais para fins de alcançar metas comerciais. 
Muitas vezes, o sujeito é levado ao excesso de trabalho digital para demonstrar a própria produtividade, o empenho em vender produtos/serviços ou ainda para promover a imagem de si mesmo e, assim, provar seu reconhecimento. Entretanto, esse sujeito esquece que, no modelo de sociedade concorrencial, competir é uma ilusão, pois há poucas ou quase nenhuma possibilidade de um pequeno empreendedor concorrer com uma grande empresa, a qual pode contratar uma agência de marketing digital que se utilize de softwares e robôs que manipulem algoritmos, com a finalidade de abrir vantagem no processo de convencer a audiência para o consumo. Mesmo assim, o discurso que aqui se analisa parece funcionar para convencer pequenos empreendedores a agirem como grandes empresas, ou melhor, como "marionetes" nas mãos dos capitalistas, como se pode perceber na sequência discursiva a seguir.

SD02 - Na sua proposta de VALOR contém [sic] as EMOÇÕES que seu cliente vai adquirir ao comprar seu produto? QUAIS AS PALAVRAS QUE VOCÊ ESTÁ DEIXANDO DE FALAR em sua narrativa de venda educacional? Muitas vezes não é conteúdo que falta, é a estratégia que está errada, a pesquisa com o cliente, 0 mapa de empatia que não está sendo explorado. Sem estratégia, você está perdendo TEMPO, ENERGIA E DINHEIRO (grifo nosso).

A busca incessante pela conquista do sucesso no meio digital, mas sem os recursos necessários para participar da concorrência, tem levado as pessoas a ficarem ansiosas e temerosas, pois renunciam ao direito ao descanso e, logo, continuam produzindo. O discurso do mercado reforça a ideia de que o sujeito precisa de uma estratégia, que já é anunciada pelo próprio mercado. Caso o sujeito não siga a rota traçada pelo capital, as sanções são de antemão anunciadas: "Você vai perder tempo, energia e dinheiro". Com essa ameaça constante, reforça-se o sentimento de medo de "ficar de fora", como define o consultor de marketing Dan Herman ${ }^{5}$, que primeiro identificou e nomeou o termo Fear of Missing Out (FoMO):

O FoMO é experimentado como uma atitude claramente temerosa em relação à possibilidade de não esgotar as oportunidades disponíveis e perder a alegria esperada associada ao sucesso em fazê-lo. Simplificando, é a concentração de atenção na metade vazia do copo (HERMAN, 2011) ${ }^{6}$.

A experiência FoMO ressalta exatamente a relação com o medo do que o sujeito sente falta porque não tem tempo ou dinheiro para a sua necessidade ou desejo. Ademais, o discurso capitalista, fortalecido pela ideologia dominante, propaga a ideia de

\footnotetext{
${ }^{5}$ No artigo "Following the Joneses: FOMO and conspicuous sociality", o pesquisador Joseph Reagle (2015) explica que o consultor de marketing Dan Herman criou o site fomofearofmissingout.com em 2011 para oferecer seus serviços e reivindicar a origem do termo FoMO com base em um artigo publicado em 2000, no Journal of Brand Management, no qual ele definiu e descreveu o termo Fear of Missing Out.

${ }^{6}$ Tradução da autora do original: "FoMO is experienced as a clearly fearful attitude towards the possibility of failing to exhaust available opportunities and missing the expected joy associated with succeeding in doing so. Simply put, it is concentration of attention on the empty half of the glass" (HERMAN, 2011).
} 
liberdade de escolhas; compartilha um princípio prático de que perder é inevitável e que, diante de uma situação com tantas possibilidades, a escolha implica renúncias. Com essa máxima ideológica, produz um sentido de insegurança e desesperança no sujeito que julga ter perdido o que poderia ter ganho se fizesse outra escolha. Esse medo de ter errado entre as supostas oportunidades é acirrado nesse mundo conectado e globalizado, em que opções de diferentes experiências foram expandidas até um infinito de possibilidades. É quando as redes sociais digitais exercem o papel fundamental de fazer com que as pessoas vivenciem o Fear of Missing Out.

De fato, viemos identificando que os discursos que elevam a importância de o sujeito estar constantemente sendo produtivo na venda/compra de produtos/serviços ampliam o sentimento de que falta algo se ele não estiver checando as redes sociais digitais com frequência suficiente para não perder nenhuma oferta de compra ou oportunidade de venda. Ainda nesse espaço virtual, as opções de acesso para ver o que os outros estão fazendo se ampliam, assim como também aumentam as possibilidades de provar que se produz mais que os outros, a fim de demonstrar produtividade. Nesse jogo, em que os sujeitos se alternam ora como voyeurs, ora como exibicionistas, o que notamos é a emergência de uma sociedade formada por pessoas cada vez mais ansiosas e movidas pelo medo de perder os predicados que as diferenciam das demais.

Numa sociedade marcada pelo medo de perder e a pressão de ser produtiva o tempo todo, essa pressão remete à ansiedade, que Courtine (2016a) reconhece de duas formas: como um traço psicológico dos indivíduos e como uma das inquietudes privadas na era do neoliberalismo generalizado. Para Courtine (2016a, p. 20), "a ansiedade é uma zona privilegiada de produção discursiva e o medo é um instrumento de governo na era da globalização neoliberal". Ele observa, ainda, que "a ansiedade, concebida como discurso, é o pré-construído do enunciado do medo" (COURTINE, 2016a, p. 26):

Os grandes medos depositam sedimentos discursivos nas memórias coletivas, das quais a ansiedade os recolhe. A ansiedade é o domínio da memória dos medos turvados, filtrados e não totalmente apagados. Os medos enterram-se nessas memórias, esboroam-se e tornam-se desconhecidos, "brancos", vazios e esquemáticos, mas não desaparecem completamente jamais. A ansiedade e os discursos que a materializam - os barulhos confusos, os rumores sem fundamentos, as notícias inquietantes, os complôs sugeridos, as predições alarmistas, os silêncios longos e amedrontadores... são absolutamente ao mesmo tempo o fantasma dos medos antigos e o presságio dos temores futuros (COURTINE, 2016a, p. 26-27).

Tal funcionamento discursivo do mercado, que provoca medo e ansiedade, não se dá a perceber imediatamente: pode-se sentir seus efeitos produzidos pelo 
silenciamento $^{7}$ de um "estado determinado de relações entre classes que compõem uma comunidade em um determinado momento de sua história" (BRANDÃO, 2012, p. 107). Isso porque o discurso silencia a relação do sujeito com seu tempo, tornando-o dependente dele e afetado pela ansiedade e pelo medo. Mais: os discursos são a trama da memória coletiva, dos temores antigos e dos medos e das ansiedades mais recentes. Nessa relação do discurso do mercado com o apelo emocional, evidencia-se a linguagem como a existência material das emoções. Ou seja, estamos diante do discurso do mercado que se vale da estratégia argumentativa das emoções (medo/ansiedade) e, para fins de interpretação, a atividade discursiva do analista equivale a

[...] depreender na ansiedade estruturas narrativas flutuantes, parcialmente submersas e amplamente indeterminadas, que comportam lugares vazios de sujeito e de objeto, mas prontas para serem convertidas em discursos do medo, carregados de ameaças e de inimigos, quando as circunstâncias históricas reclamam-nas e quando tais narrativas voltam à tona (COURTINE, 2016a, p. 26).

Com os estudos de Courtine (2016a) acerca da história da sensibilidade, identifica-se que o discurso da ansiedade é constituído de memória discursiva que funciona na ordem do dizer de outros discursos flutuantes de medos antigos, que podem se tornar a matriz discursiva de novos medos, deslocados em direção a novos objetos. Somado a isso, há ainda outra dimensão nesse processo discursivo: a inveja solitária motivada pela exclusão social.

O medo de perder ou de ser deixado de fora estimula os sujeitos a reagirem à demonstração da grandiosidade de outros de forma que produzam ainda mais conteúdo promocional nas mídias sociais, levando a uma espiral discursiva ${ }^{8}$, isto é, a um discurso que se retroalimenta e se movimenta por meio de uma curva que gira em torno de um ponto central, dele se afastando ou se aproximando, segundo a lei determinada pelo capital. A espiral discursiva funciona quando, ao promover seu produto/serviço ou a sua própria produtividade, o sujeito explora o medo no outro, por meio da mesma ameaça que o aflige. Desse modo, o outro é então ainda mais afetado pelo medo e todas as suas formas de expressão, reagindo a um processo de autopromoção que se retroalimenta.

O que resulta desse processo é um sujeito sempre online, numa prontidão emblemática e, assim, sente-se contraditoriamente "seguro" porque inflige o mal no outro, mal que também o aflige. Isso acontece por saber que pode exibir sua produtividade e se manter informado sobre a produção dos seus concorrentes o tempo

\footnotetext{
7 Em "Análise de Discurso: princípios e procedimentos", Eni Orlandi (2015) esclarece que o silenciamento se trata, dentre as formas de não-dito, de uma política do silêncio, na qual um discurso apaga outros discursos.

${ }^{8}$ Este conceito de autoria de Danielle Cândido está sendo mais bem construído na sua tese de doutorado.
} 
todo. Em outras palavras, fomentam a concorrência, afastando a insegurança da exclusão social, ao incutir no outro o medo, a ansiedade e a inveja da qual também padecem. Desse modo, os sujeitos encontram nas redes sociais digitais o espaço apropriado para comprovar que estão produzindo e respondendo às necessidades ditadas pela vida na sociedade de consumo; parecem ser únicas, exclusivas por serem produtivas em um contexto tão adverso propagado pela ilusão da possibilidade de participar da concorrência.

É importante ressaltar que o discurso do mercado produz o efeito de sentido de concorrência, isto é, "um efeito ideológico que provoca no gesto de interpretação a ilusão de que um enunciado quer dizer o que realmente diz (sentido literal)" (FERREIRA, 2001, p. 14). Esse efeito consiste na ilusão de que o crescimento da riqueza e a sua transformação em capital pode ser um processo infinito. Com esse argumento "ilusório", os sujeitos são movidos pela concorrência (mas não participam dela) e agem conforme a manipulação dos capitalistas e de seus recursos. Para esse funcionamento discursivo, a crença na concorrência e na liberdade de escolha é um componente essencial da ideologia capitalista para perpetuar o desejo de comprar/vender e o de possuir e ser.

O argumento do discurso de mercado, hoje involucrado como empreendedorismo digital, como vimos nas SDs até então analisadas, recebe a adesão do sujeito trabalhador, uma vez que, sem leis trabalhistas e sem políticas de incentivo ao pleno emprego, inevitavelmente se observa o crescimento do desemprego e da precariedade do trabalho, fazendo com que cada vez mais pessoas aceitem qualquer forma de ocupação e de geração de renda, em qualquer condição, para se sustentarem. Nesse contexto, em que se verifica um aumento na concorrência entre trabalhadores, uma explosão do exército de reserva e um tecido social em que qualquer exclusão do trabalho representa estar ligado à própria sorte, há um ambiente de constante ansiedade diante do medo da miséria. Por isso que se sustenta a tese de que a ansiedade e o medo são afetos centrais no neoliberalismo, que impelem as pessoas a não questionarem o sistema e a aceitarem qualquer condição de (sobre)vida.

Com efeito, percebe-se que o modo como opera a modalidade discursiva argumentativa baseada na emoção (medo e ansiedade) perpassa os meios discursivos logos, ethos e pathos. Em se tratando do comportamento FoMO, o discurso do medo apresenta um argumento racional (logos) da necessidade de pertencimento ao grupo de vendedores de sucesso ou consumidores em potencial; o sujeito do discurso (ou porta-voz do discurso do capital, a mentora digital) emerge da construção de uma imagem de poder e influência (ethos) sobre o outro; este outro, por sua vez, é arrebatado pelo discurso que se endereça ao sentimento em detrimento da reflexão (pathos), o que leva à ansiedade de atender às necessidades ou aos desejos impostos pela sociedade de consumo, devido ao medo de perder dinheiro, poder e prazer. 


\section{Discurso e argumentação}

Sobre os aspectos do discurso e argumentação, toma-se, inicialmente, Aristóteles, para quem a argumentação é sinônimo de retórica clássica ou da arte de persuadir: "Arte de bem dizer, arte de persuadir, arte moral, eis os elementos implícita ou explicitamente verificados em quase todas as definições de retórica" (ARISTÓTELES, 2012, XXI). Numa concepção mais ampla, a argumentação é conhecida como a tentativa de o emissor modificar a visão do receptor, pelos recursos da linguagem. Já Amossy (2011) aponta uma definição que amplia a "da nova retórica de Perelman, pela tentativa de fazer aderir não somente a uma tese, mas também a modos de pensar, de ver, de sentir" (AMOSSY, 2011, p. 130).

Ao entender que a argumentação apenas surge quando é possível haver uma discordância, visto que não se argumenta sobre o que é evidente, Amossy (2011) expõe dois conceitos fundamentais acerca das estratégias discursivas da argumentação - a intenção argumentativa e a dimensão argumentativa -, os quais se utilizam do consenso para estabilizar o que não é evidência em evidência. Amossy (2011, p. 132) entende a intenção argumentativa como "estratégia de persuasão programada", quando há intenção explícita de persuadir o outro. Tal estratégia discursiva da argumentação - a intenção argumentativa -, é demonstrada na sequência discursiva a seguir.

SD 03 - Pessoas não compram produtos ou serviços. Pessoas compram transformações que eliminam medo/dor e conquistam sonhos/desejos.

Desde a Retórica de Aristóteles às atuais estratégias discursivas da publicidade e propaganda, as artimanhas da linguagem se utilizam de modalidades argumentativas. $\mathrm{Na}$ SD03, inscreve-se um movimento entre o discurso publicitário ${ }^{9}$ e o discurso do mercado, expressando a interdiscursividade no cenário digital. O post, de caráter educativo, tem a missão de ensinar aos seguidores/consumidores do perfil @keylagabrielleoficial sobre como persuadir o outro para a compra de produtos ou serviços, a fim de que esses seguidores atinjam o sucesso profissional com o lucro das vendas online. Para alcançar esse objetivo, o texto (materialidade linguístico-discursiva em análise), aparentemente pedagógico, instrui sobre a estratégia discursiva do mercado de forma velada. Segundo Amaral (2016, p. 157), o discurso pedagógico "reveste-se de competência para definir conceitos, divulgar novas ideias e explicitar sentidos". Isto é, a interdiscursividade mercado-publicidade-pedagógico apresenta a mentora digital como aquela que "detém o saber e está capacitada para ensinar, transmitir informações” (AMARAL, 2016, p. 157).

\footnotetext{
9 De acordo com Aires e Hoff (2016), o discurso publicitário é um dos mais potentes discursos presentes na esfera do consumo na contemporaneidade, fazendo do próprio consumo um projeto de vida.
} 
Por se tratar de um texto educativo, o caráter de instrução é marcado pelo uso dos verbos no imperativo ("para", "se concentre", "não esqueça", "busque", "corrija", "avance"), conforme pontuamos na SD01. O imperativo representa uma ordem ou uma sugestão para o sujeito que quer se tornar um sucesso de vendas na mídia digital. A própria progressão dos verbos (retirados da legenda do post na mesma ordem de apresentação) demonstra um efeito de evolução para o sujeito que segue as instruções fornecidas pela mentora, a qual exerce um papel de porta-voz do discurso do mercado. Nas palavras de Pêcheux (1990, p. 17), o porta-voz representa "ao mesmo tempo ator visível e testemunha ocular do acontecimento".

[...] o efeito que ele exerce falando "em nome de..." é antes de tudo um efeito visual, que determina esta conversão do olhar pela qual o invisível do acontecimento se deixa enfim ser visto: o porta-voz se expõe ao olhar do poder que ele afronta, falando em nome daqueles que representa, e sob o seu olhar. Dupla visibilidade (ele fala diante dos seus e parlamenta com o adversário) que o coloca em posição de negociador potencial, no centro visível de um "nós" em formação e também em contato imediato com o adversário exterior (PÊCHEUX, 1990, p. 17).

No discurso do mercado, o porta-voz fala em nome dos agentes políticos e econômicos e propaga, enquanto tal, o efeito da positividade empreendedora por meio do ato de educar para inspirar e promover a competitividade no mercado com atitudes cada vez mais desumanas - a exemplo da degradação das condições de trabalho nas sociedades contemporâneas - e, no caso em questão, utiliza-se do ambiente online para persuadir o outro. Ademais, as expressões de mando (expressas pelos verbos no imperativo) apontam para a relação de obediência/subordinação na sociedade que se dá pelas relações de troca. Expressões que anunciam, por meio de um discurso lógicoformal coerente, que a intenção argumentativa busca "aconselhar ou desaconselhar sobre uma questão de interesse geral ou particular" (CARRASCOZA, 2004, p. 39), a exemplo da instrução sobre como vender pela internet.

Pode-se identificar, também, que a SD03 se utiliza de argumentos emocionais qual seja, discursos que apelam pelo caráter emocional, conforme explica Carrascoza (2004) - na tentativa de convencer o outro para aderir a uma vida destinada para o consumo. Isso porque, para o funcionamento da estratégia discursiva do mercado, entende-se, a partir de Solomon (2016), que os profissionais de marketing devem identificar os diferentes desejos e necessidades dos diferentes segmentos de consumidores para então pensar nas estratégias discursivas da argumentação. Nesse percurso, a trama discursiva é elaborada a partir da interseção entre o interesse do discurso do mercado (persuadir para o consumo) e o desejo dos consumidores (evitar a dor e conquistar o prazer), conforme está expresso na SD03 e que se pode identificar na Figura 2. 
Figura 2 - Intersecção entre os discursos do mercado e do consumidor

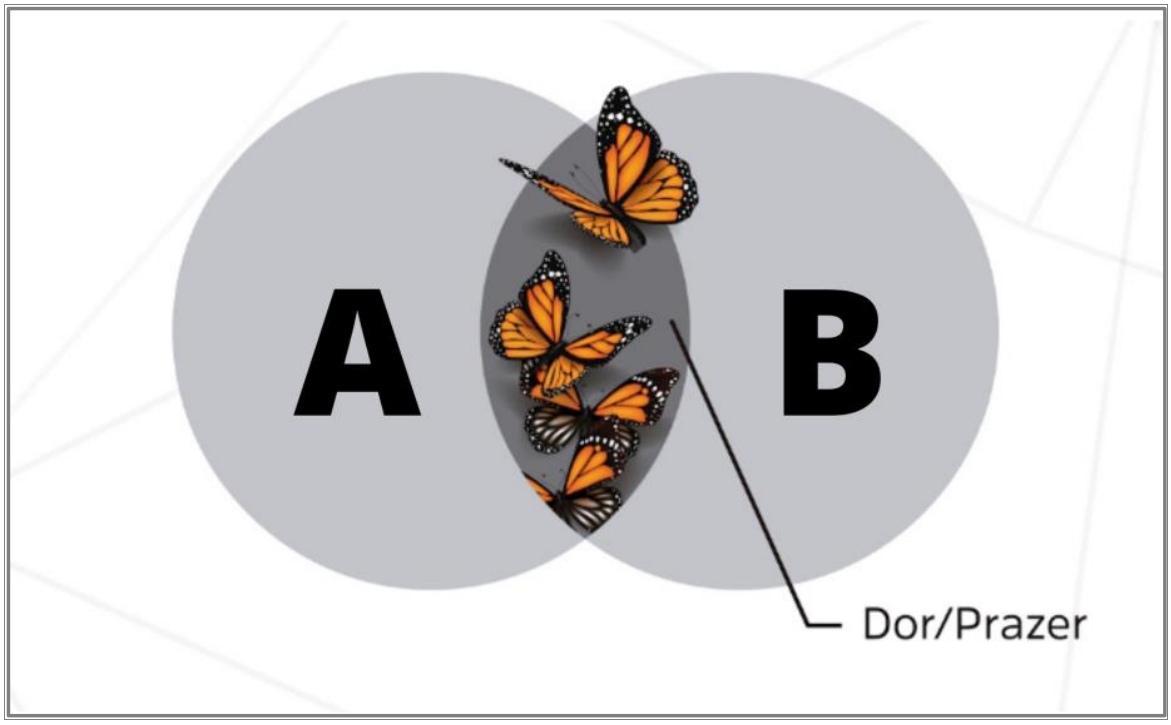

Fonte: Elaboração própria

A Figura 2 ilustra o processo de interseção entre o interesse do mercado (A) e o desejo dos consumidores (B). Esse interesse/desejo está presente no discurso ${ }^{10}$, que é produzido de modo a resolver um problema ou proporcionar uma experiência boa ao consumidor (B), de forma que, nesse processo persuasivo, acontece também a "venda" do produto/serviço $(A)$, o que atende aos interesses econômicos. Para tanto, estudos de comunicação e consumo (AIRES, HOFF, 2016; CARRASCOZA, 2014) apontam que as estratégias argumentativas do mercado funcionam com ênfase nas emoções (pathos) e, por essa razão, o discurso é ilustrado pelas imagens de borboletas, devido ao efeito de metamorfose representado pelos sentidos aparentes (eliminar medo/dor e conquistar sonhos/desejos) e opacos (as relações de consumo como base no modelo de sociabilidade neoliberal) da discursividade em análise, assim como acontece com o efeito de transformação da lagarta em borboleta.

Nessa linha, nota-se que, tanto nos argumentos que buscam a solução de problemas (dor) como naqueles que melhoram alguma situação (prazer), a argumentação busca o consenso com a finalidade de adesão. Nesse sentido, identificase que alguns dos elementos de saber do discurso do mercado que se apoiam na "dor" são caracterizados pelos argumentos que tentam assustar com o que aconteceu com outra pessoa devido a um mesmo comportamento negativo, ou fazendo-a imaginar-se em uma situação terrível para impedir um comportamento negativo. A sequência discursiva 04 (SD04) demonstra esse funcionamento discursivo, categoria definida por Orlandi (1983, p. 184) como "uma atividade estruturante de um discurso determinado,

10 Toma-se o "discurso" a partir de Pêcheux, que Orlandi (2015, p. 19-20) traduziu como "efeito de sentidos entre locutores". 
por um falante determinado, para um interlocutor determinado, com finalidades específicas". Filiando-nos ao teorizado pela autora, compreendemos que texto e discurso se determinam mutuamente, são interdependentes.

SD04 - Corrija a ROTA e pare de andar em círculos que não te fazem prosperar e só cansar [sic], sem resultados.

Na SD04, observa-se o caráter de instrução presente no discurso, por meio dos verbos no imperativo ("corrija", "pare"). "ROTA", grafada em caixa alta, representa o caminho que o sujeito deve percorrer para conquistar o sucesso com as vendas online. É importante ressaltar que, no discurso do capital, engendrado para criar nos sujeitos uma ideologia de dependência, não há opção de escolha, visto que as escolhas já estão determinadas e traçadas como "rota". Ou seja, numa sociedade que erroneamente identifica liberdade com a escolha privada e a vida privada, a qual Slater (2002, p. 32) descreveu como "uma sociedade de escolhas e da soberania do consumidor", essa concepção de "escolha" do consumidor como "liberdade" é resultado da naturalização de um modo de produção (o capitalista) que se mantém exatamente porque impossibilita o indivíduo de enxergar outras possibilidades.

Todavia, Lessa e Tonet (2011, p. 118) ressaltam que inexiste uma possibilidade "intermediária entre o capitalismo e a sociedade emancipada, comunista. Não há capitalismo 'humano', pois a essência da sociedade capitalista é a produção crescente de desumanidades". É preciso entender que a sociedade de consumo está além da observação trivial de que os membros da sociedade consomem, em detrimento da fase industrial em que era uma sociedade de produtores. Trata-se, portanto, de uma sociedade que precisa engajar seus membros na condição de consumidores. A atual sociedade de consumo - um mundo autorreferente, abstrato e que gira em torno de si mesmo (BAUMAN, 2008) - leva à reflexão de que é necessário ir além do fenomênico e perceber que o que caracteriza a sociedade capitalista face aos modos de produção anteriores é a redução da força de trabalho à condição de mercadoria, desprezando-se em absoluto as necessidades humanas.

Com esse entendimento, identificam-se, ainda, as dores e os medos por que passam os sujeitos (explorados pelo discurso do mercado), evidenciados pelas expressões "andar em círculos", "que só te fazem cansar" e "sem resultados". O próprio "andar em círculos" remete a algo inerte, que não sai do lugar, ou que se repete sem finalidade ou transformação - características completamente opostas ao espírito empreendedor do capitalismo e ao desejo dos consumidores, conforme ilustrado na SD03: "Pessoas compram transformações". O discurso do mercado é, ademais, atravessado pelo discurso religioso, qual seja, aquele que faz ouvir a voz de Deus ou de seus enviados. Esse discurso se utiliza das estratégias discursivas da autoajuda e 
se camufla de religião, como se pode identificar com o verbo "prosperar", relativo àquele com bom êxito e que ganha muito.

No caso do discurso do mercado que se apoia no "prazer", alguns dos elementos de saber estão presentes ao fazer rir, tentando transferir aquela emoção de um grupo social ou tendência para um produto/serviço "divertido"; ou ainda ao tentar impressionar, inspirar e vincular o fator "impressionante" e "inspirador" a uma promessa de marca/produto/serviço. $\mathrm{Na}$ sequência discursiva a seguir, demonstra-se esse funcionamento discursivo com um trecho extraído do post em análise.

SD05 - Você sabia que existem PALAVRAS-CHAVE que são códigos de ACESSO ao universo do seu cliente? Um dia assistindo um Storie de uma Blogueira [sic], ela fez uma indicação de um perfume, usando as palavras EXATAS que conectavam comigo, que era a sua Persona. Quando eu terminei de ver os Stories dela, fui atrás do perfume na loja e comprei. Ela falou exatamente o que eu queria e como eu queria me sentir. Detalhe: ela não fez uma venda técnica, longe disso. Fez uma venda líquida, com entretenimento, leve, emocional e conectada com o que eu queria me tornar, após usar o perfume. Entendeu? Você está vendendo técnica ou transformação?

$\mathrm{Na}$ SD05, observa-se o discurso publicitário realizando-se como prática de linguagem e, ao circular socialmente na rede digital, apresenta o objetivo básico de influenciar o comportamento do internauta por meio de apelos que visam à adesão ao consumo. Para isso, a utilização do pronome de tratamento informal "você" é fundamental para fazer funcionar um apelo direto ao leitor, valendo-se assim de aspectos da oralidade com fins expressivos, como se houvesse familiaridade entre emissor e receptor. O que se verifica no discurso em análise são elaborações criativas, intencionais e com objetivos previamente definidos, que procuram imitar a coloquialidade da fala espontânea. É possível ainda afirmar que o aproveitamento da oralidade no discurso publicitário ocorre de modo parecido com o que se dá em certas vertentes da literatura, em que são apresentados ao leitor diálogos artificiais que provocam a ilusão de naturalidade. Sobre esse efeito da linguagem, Carvalho (1996, p. 13) considera que:

Toda a estrutura publicitária sustenta uma argumentação icônico-linguística que leva o consumidor a convencer-se consciente ou inconscientemente. Tem a forma de diálogo, mas produz uma relação assimétrica, na qual o emissor, embora use o imperativo, transmite uma expressão alheia a si própria. $O$ verdadeiro emissor permanece ausente do circuito da fala; o receptor contudo é atingido pela atenção desse emissor em relação ao objeto.

O tom de diálogo informal que o discurso tenta estabelecer com o leitor está presente também no teor pessoal (a utilização do pronome pessoal "eu") e no teor confessional do discurso publicitário, a fim de reafirmar, constatar e dar credibilidade ao que é anunciado/ofertado pelo porta-voz do discurso. Outra estratégia argumentativa 
presente na SD05 é o uso de caixa alta. "PALAVRAS-CHAVE", "ACESSO" e "EXATAS" funcionam como uma linha de força do discurso do mercado, de modo que o texto constitui um grande poder persuasivo. Um guia que orienta o modo de querer, pensar e agir do sujeito consumidor.

Outra questão relevante a pontuar é que o discurso neoliberal se apoia também na ideia do "prazer", no sentido de compartilhar um testemunho para resolver um problema ou proporcionar uma experiência boa ao consumidor, a fim de propagar uma promessa, uma fantasia, uma quimera, um sonho - bastante contrário ao que ele se revela. Pode-se identificar esse discurso da promessa na primeira frase da SD05, em forma de pergunta, "Você sabia que existem PALAVRAS-CHAVE que são códigos de ACESSO ao universo do seu cliente?", como também na expressão "Ela falou exatamente o que eu queria e como eu queria me sentir", que demonstra a promessa de transformação que o mercado proporciona.

Esse discurso de promessa da liberdade, ou seja, de que você pode "vender os benefícios dos seus produtos/serviços" no mercado online, é construído como crítica à alienação que sustenta a restrição da liberdade individual, levando o sujeito consumidor a acreditar e a seguir a promessa do projeto neoliberal. Isso acontece porque o projeto garante, no presente, uma espécie de liberdade individual que, vale destacar, não apresenta opções de escolha, visto que a única possibilidade é a sociedade de consumo (DARDOT, LAVAL, 2016). Ademais, promete um futuro economicamente promissor, mas preso a um vir-a-ser que nunca chega, à custa de muitos sofrimentos. Esta reflexão está posta na última frase da SD05, "Entendeu? Você está vendendo técnica ou transformação?", deslocando para o sujeito a responsabilidade pelo seu lugar no mercado a partir da sua capacidade de transitar no universo digital e de acessar a chave que o leva ao universo do cliente.

Quando se fala que o discurso do mercado produz sofrimento, depara-se com uma questão complexa. Isso decorre do fato de que o funcionamento discursivo do projeto neoliberal depende de certos níveis de tensão para manter os sujeitos produtivos, a saber: cria-se uma sociedade de todos contra todos e sujeitos que agem individualmente; elimina-se qualquer aparato institucional de solidariedade e de proteção ao trabalhador; e mercantiliza-se tudo para que todos sejam reféns de uma única lógica, a do mercado. Assim, sem políticas de proteção e com tudo mercantilizado, resta o mercado para prover as necessidades das pessoas, que só conseguem assim satisfazê-las com dinheiro - o que é potencialmente mais difícil sem leis trabalhistas que assegurem uma renda estável aos indivíduos. Desse modo, surgem os sofrimentos enaltecidos pelo medo/ansiedade de uma vida para o consumo.

Após havermos explanado acerca da intenção argumentativa, observa-se que, na dimensão argumentativa (a outra estratégia discursiva da argumentação), "a estratégia 
de persuasão é indireta e, muitas vezes, não admitida" (AMOSSY, 2011, p. 132). O próprio discurso da publicidade muitas vezes se utiliza do discurso híbrido, ou seja, um discurso que apresenta, pelas suas marcas discursivas, uma mistura de dois discursos: o do jornalismo, que se faz neutro, para "anunciar" a intenção da publicidade ${ }^{11}$, a fim de orientar os modos de ver do interlocutor. Isto remete ao princípio essencial da publicidade, que é o de "esconder, o mais possível, o intuito publicitário", de autoria do poeta Fernando Pessoa (apud FERREIRA, 1986, p. 148) conforme comentado anteriormente. Pode-se notar que, seja na intenção, seja na dimensão argumentativa, o discurso do mercado não é admitido de forma objetiva. Para interpretar o caráter indireto da estratégia argumentativa do mercado, a identificação dos elementos de saber que fazem funcionar as estratégias de argumentação no discurso são essenciais para o gesto de interpretação da/o analista do discurso, como se pôde observar nos elementos que se apoiam na dor/prazer para fins de convencimento.

Portanto, o que é importante é identificar e analisar a maneira como esses discursos destinados a, antes de tudo, informar, descrever, narrar, testemunhar, direcionam o olhar do alocutário para fazê-lo perceber as coisas de uma certa maneira. Em todos os casos, a argumentação é inseparável do funcionamento global do discurso, e deve ser estudada no quadro da Análise do Discurso (AMOSSY, 2011, p. 132).

Entende-se, pois, que a Teoria da Argumentação contribui para a análise, visto que é papel do analista pensar o processo de produção do discurso antes mesmo de analisar os seus efeitos de sentido. Isso porque, segundo Pêcheux, todo critério puramente linguístico é insuficiente para caracterizar os processos discursivos daquilo que "numa formação ideológica dada [...] determina o que pode e deve ser dito" (PÊCHEUX, 2014, p. 147).

Nesse sentido, a argumentação contribui no processo de identificação dos elementos de saber de dada formação discursiva e de como esses elementos fazem funcionar a estratégia de persuasão analisada na perspectiva da teoria materialista do discurso. Amossy (2011, p. 132) destaca ainda que "a argumentação aparece como um encadeamento de proposições lógicas que temos de debrear da língua natural que as veicula e disfarça, simultaneamente", complementando que o analista "é responsável por atualizar a armadura em que se sustenta a argumentação, o esqueleto escondido sob a carne das palavras" (AMOSSY, 2011, p. 132). Como também observa Plantin (1995 apud AMOSSY, 2011, p. 132), "a língua natural não é um obstáculo, mas a condição da argumentação".

11 Ver Mello e Emediato (2013). 


\section{Considerações finais}

O lugar da Argumentação na Análise do Discurso (AD) francesa foi uma das questões levantadas por este artigo, que refletiu sobre as estratégias do discurso argumentativo na sociedade conectada ao consumo. Essa proposta de aproximação entre a argumentação e a AD, a partir do diálogo teórico de Amossy $(2011 ; 2018)$ e Pêcheux (2014), provocou questionamentos que levaram a novos conhecimentos e a possibilidades de interlocuções nos estudos da Linguística, tendo como base a história da metamorfose recíproca do medo em ansiedade, como descreve Courtine (2016a), na sociedade de consumo e seus sofrimentos contemporâneos, a exemplo do comportamento FoMO, o "medo de ficar de fora".

Identificou-se que o apelo ao medo é uma forma de a lógica capitalista conseguir submissão e aquiescência dos sujeitos, que formam uma prontidão emblemática e ansiosa em busca de segurança. Com base nos elementos de saber do discurso do mercado, as estratégias argumentativas que se apoiam na emoção para fins de convencimento (pathos) apresentaram uma aparência social de ordem, enquanto a sua essência é o de controle político, econômico e social, com o objetivo de o capitalismo enquanto sistema permanecer no poder. A porta-voz do discurso do capital fez isso utilizando-se da empatia, da capacidade de extrair a emoção do público - inclusive, emoções ruins, como medo e ansiedade, foram utilizadas pela mentora digital com o intuito de atrair a audiência. Pode-se concluir, destarte, que sentimentos convencem e que a persuasão é amparada por um discurso emocionado.

Ainda para esse efeito persuasivo, a porta-voz do discurso do mercado (a mentora digital), munida da força de seu ethos, utilizou-se de estratégias discursivas que foram observadas, descritas e interpretadas na relação entre a transparência e a opacidade da linguagem: enquanto promoveu a necessidade de divulgação de produtos/serviços, ocultou que a concorrência é um efeito que leva o sujeito a pensar que pode participar e competir na sociedade de mercado. Isto é, propagou-se uma ilusão, um efeito de concorrência. A figura do porta-voz foi importante na estratégia de persuasão porque possui autoridade para com o público e é reconhecido pela boa moral. Isso significa que o porta-voz pode modelar a percepção do público, como pudemos observar no discurso analisado, pelo qual se compartilham experiências, usa-se de linguagem amigável, apresenta uma vontade de ajudar e passar segurança em ensinar.

Já o logos, o terceiro dos polos do empreendimento de persuasão retórica, representa o espírito de razão no discurso. No discurso publicitário, a ênfase na lógica não é mais tão utilizada como antes, pois se identificou que os argumentos emocionais têm um poder maior de persuasão, uma vez que as estratégias discursivas com foco na emoção acendem uma centelha de ideias na cabeça do público. Mesmo assim, há traços da argumentação racional no discurso que tentou convencer e, por isso, o 
argumento que se apoia na razão é importante para provar logicamente o que está sendo dito.

O diálogo da Análise do Discurso francesa com a Teoria da Argumentação e os estudos da comunicação e consumo apresentaram um caminho para pensar a história das metamorfoses recíprocas dos medos em ansiedades nas sociedades de consumo imersas no ambiente digital, bem como analisar seus discursos e efeitos de sentido. Como defende Amossy (2011), em vez de ver nessa interlocução uma confusão desagradável, é possível identificar uma conveniente interdisciplinaridade que responda às inquietações da pesquisa, ampliando, assim, as possibilidades de interlocução no campo da Linguística.

\section{Agradecimentos}

Este trabalho foi realizado com apoio da FAPEAL (Fundação de Amparo à Pesquisa do Estado de Alagoas), com bolsa de doutorado para Danielle Cândido, e do CNPq (Conselho Nacional de Desenvolvimento Científico e Tecnológico), com bolsa PQ para Maria Virgínia Borges Amaral.

\section{Referências}

AIRES, Aliana Barbosa; HOFF, Tânia Márcia César. Inter-relações entre os estudos de comunicação/consumo e da análise de discurso francesa: uma perspectiva para investigar publicidade. In: XXXIX Congresso Brasileiro de Ciências da Comunicação (INTERCOM), 2016, São Paulo, Anais [...]. São Paulo: Intercom, 2016. Disponível em: https://portalintercom.org.br/anais/nacional2016/resumos/R11-2296-1.pdf. Acesso em: 2 dez. 2021.

AMARAL, Maria Virgínia Borges. Discurso e relações de trabalho. 2.ed. Maceió: Edufal, 2016.

AMOSSY, Ruth. Argumentação e Análise do Discurso: perspectivas teóricas e recortes disciplinares. Tradução: Eduardo Lopes Piris e Moisés Olímpio Ferreira. EID\&A - Revista Eletrônica de Estudos Integrados em Discurso e Argumentação, llhéus, n.1, p. 129-144, nov. 2011. Disponível em: http://periodicos.uesc.br/index.php/eidea/article/view/389/395. Acesso em: 2 dez. 2021.

AMOSSY, Ruth. A argumentação no discurso. Coordenação de tradução: Eduardo Lopes Piris e Moisés Olímpio-Ferreira. Tradução: Ângela M. S. Corrêa et al. 1.ed. São Paulo: Contexto, 2018.

ARISTÓTELES. Retórica. Tradução: Manuel Alexandre Júnior, Paulo Farmhouse Alberto e Abel do Nascimento Pena. 1.ed. São Paulo: WMF Martins Fontes, 2012. 
BAUMAN, Zygmunt. Vida para consumo: A transformação das pessoas em mercadoria. Tradução: Carlos Alberto Medeiros. 1.ed. São Paulo: Zahar, 2008.

BRANDÃO, Helena Hathsue Nagamine. Introdução à análise do discurso. 3.ed. Campinas: Editora da Unicamp, 2012.

CARRASCOZA, João Anzanello. Razão e sensibilidade no texto publicitário. 1.ed. São Paulo: Futura, 2004.

CARRASCOZA, João Anzanello, Estratégias criativas da publicidade: consumo e narrativa publicitária. 1.ed. São Paulo: Estação das Letras e Cores, 2014.

CARVALHO, Nelly de. Publicidade: a linguagem da sedução. 1.ed. São Paulo: Ática, 1996.

COURTINE, Jean-Jacques. A era da ansiedade: discurso, história e emoções. Tradução: Denise Ribeiro Leppos, Joseane Bittencourt e Carlos Piovezani. In: CURCINO, Luzmara; SARGENTINI, Vanice; PIOVEZANI, Carlos (ogs.). (In)subordinações contemporâneas: consensos e resistências nos discursos. 1.ed. São Carlos: EdUFSCar, 2016a.

COURTINE, Jean-Jacques. Definição de orientações teóricas e construção de procedimentos em Análise do Discurso. Tradução: Flávia Clemente de Souza e Márcio Lázaro Almeida da Silva. LABEDIS - Revista do Laboratório de Estudos do Discurso, Imagem e Som, Rio de Janeiro, v. 1, n. 1, p. 14-35, jun. 2016b. Disponível em: https://revistas.ufrj.br/index.php/policromias/article/view/4090 Acesso em: 2 dez. 2021.

DANTAS, Valná. Na era das pessoas, comunicar sua marca colocando o consumidor no centro do seu discurso faz toda a diferença. Maceió. 29 set. 2021. Instagram: @valna.dantas Disponível em https://www.instagram.com/p/CUaOPeQL2PP/ Acesso em 30 set. 2021.

DARDOT, Pierre; LAVAL, Christian. A nova razão do mundo: ensaio sobre a sociedade neoliberal. Tradução: Mariana Echalar. 1. ed. São Paulo: Boitempo, 2016.

O ESTADO DE S. PAULO. Fomo; o medo de ficar por fora. Disponível em https://link.estadao.com.br/noticias/geral,fomo-o-medo-de-ficar-por-fora, 10000038220

Acesso em: 29 nov. 2021.

FERREIRA, António Mega (org). Fernando Pessoa: o comércio e a publicidade. 1.ed. Lisboa: Cinevoz; Luzomedia, 1986.

FERREIRA, Maria Cristina Leandro (coord.). Glossário de Termos do Discurso. 1.ed. Porto Alegre: UFRGS, 2001.

GABRIELLE, Keyla. Leia esse texto: 0 que as pessoas compram, na verdade? Maceió. 3 set. 2021. Instagram: @keylagabrielleoficial Disponível em https://www.instagram.com/p/CEq6Y3jp0Kw/ Acesso em: 9 set. 2021.

HAN, Byung-Chul. Sociedade do cansaço. Tradução: Enio Paulo Giachini. 1.ed. Rio de Janeiro: Vozes, 2015.

HERMAN, Dan. The fear of missing out. In: The fear of missing out. 2011. Disponível em: http://fomofearofmissingout.com/fomo. Acesso em: 5 ago. 2020.

LESSA, Sérgio; TONET, Ivo. Introdução à Filosofia de Marx. 2. ed. São Paulo: Expressão Popular, 2011. 
MARI JR, Sergio; MICHELAN, Vanessa Silva. O meme como linguagem da inteligência coletiva. Comunicologia, v. 12, n. 1, p. 69-87, jan./jun. 2019. Disponível em: https://portalrevistas.ucb.br/index.php/RCEUCB/article/view/10295/6237 Acesso em: 2 dez. 2021.

MELLO, Shirlei Maria Freitas de; EMEDIATO, Wander. Informação jornalística, publicidade e propaganda. In: EMEDIATO, Wander (org.). A construção da opinião na mídia. Belo Horizonte: NAD; FALE; UFMG, 2013. p. 243-266.

NATULINI, Julia (2021). \#foradostory, você tá bem? Disponível em https://www.terra.com.br/vida-e-estilo/saude/foradostory-voce-tabem,ef7d71a8375059826dd56f5b6f1d8de4bitju9sj.html Acesso em 29 nov 2021.

ORLANDI, Eni Pucinelli. A linguagem e seu funcionamento: as formas do discurso. 1.ed. São Paulo: Brasiliense, 1983.

ORLANDI, Eni Pucinelli. Análise de Discurso: princípios e procedimentos. 12.ed. Campinas: Pontes, 2015.

PÊCHEUX, Michel. Semântica e discurso: uma crítica à afirmação do óbvio. Tradução: Eni Puccinelli Orlandi et al. 5.ed. Campinas: Editora da Unicamp, 2014.

PÊCHEUX, Michel. Delimitações, inversões, deslocamentos. Cadernos de Estudos Linguísticos, Campinas, v. 19, p. 7-24, 2012. Disponível em: https://periodicos.sbu.unicamp.br/ojs/index.php/cel/article/view/8636823. Acesso em: 2 dez. 2021.

REAGLE, Joseph. Following the Joneses: FOMO and conspicuous sociality. First Monday, Chicago, v. 20, n. 10, 5 out. 2015. Disponível em: https://doi.org/10.5210/fm.v20i10.6064. Acesso em: 2 ago. 2020.

SLATER, Don. Cultura do consumo \& modernidade. Tradução: Dinah de Abreu Azevedo. 1.ed. São Paulo: Nobel, 2002.

SOLOMON, Michael R. Comportamento do consumidor: comprando, possuindo e sendo. Tradução: Beth Honorato. 11.ed. Porto Alegre: Bookman, 2016. 